\title{
Sodium, potassium, and rate constants for sodium efflux in leucocytes from hypertensive Jamaicans
}

\author{
TERRENCE E FORRESTER， GEORGE A O ALLEYNE
}

\begin{abstract}
Leucocyte sodium and potassium content and concentrations were measured along with ouabain-sensitive and ouabain-insensitive rate constants for sodium efflux in 14 controls and 20 black patients with essential hypertension. Leucocyte sodium content was significantly increased in the patients (mean $101.1 \pm 7.8 \mathrm{mmol} / \mathrm{kg}$ dry solids $v 74.5 \pm 7.6 \mathrm{mmol} / \mathrm{kg}$ dry solids; $p<0.05$ ), whereas the rate constants for sodium efflux were not significantly reduced. There was no difference between the two groups in cell potassium values.

The increase in leucocyte sodium content in the presence of normal rate constants for sodium efflux suggests an increase in membrane permeability to sodium, which might be important in the pathogenesis of essential hypertension.
\end{abstract}

\section{Introduction}

Specific disturbances in sodium metabolism occur in essential hypertension, and attention has been focused on their significance in the pathogenesis of hypertension. Eyer ${ }^{1}$ reported that blood pressure does not rise with age in populations with a nonWesternised life style and a small dietary intake of sodium chloride, but Dahl and Love described a positive correlation between salt intake and the prevalence of hypertension in several populations. ${ }^{2}$ They also showed a difference in the prevalence of hypertension in adults positively correlated with urinary excretion of sodium, and later developed the concept of a genetically determined sensitivity to the hypertensinogenic effect of salt by breeding salt-resistant and salt-sensitive strains of rats. ${ }^{3}{ }^{4}$

More recently increased erythrocyte membrane transport of potassium in patients with mild hypertension and a decrease in the transport of sodium in severe hypertension have been

University of the West Indies, Mona, Kingston 7, Jamaica TERRENCE E FORRESTER, MB, PHD, department of medicine GEORGE A O ALLEYNE, MD, FRCP, professor of medicine described $^{5}$; thus in mild or severe essential hypertension the ratio of sodium to potassium fluxes was always depressed. There were identical alterations in sodium and potassium flux ratios in non-hypertensive children of hypertensive parents. Other workers have reported increased erythrocyte sodium and lithium countertransport in patients with essential hypertension and also in first-degree relatives of such patients. ${ }^{6}$ Increased leucocyte sodium and cell water and a reduced rate constant for sodium efflux in patients with essential hypertension have also been described. ${ }^{7}$ It is thus becoming clear that there are differences in sodium metabolism in hypertensive patients and, more fundamentally, that these differences may be related to changes or abnormalities of membrane transport of ions.

All of the later studies mentioned were in white subjects. In black populations hypertension is more prevalent, more severe, and associated with relatively greater morbidity and mortality than in white populations. We have therefore studied leucocyte sodium, potassium, and rate constants for sodium efflux in black hypertensive Jamaicans to try to determine the presence and nature of any abnormalities in cellular sodium homoeostasis.

\section{Methods}

Twenty patients with essential hypertension were chosen from the hypertension clinic at this hospital. Patients with secondary causes for hypertension or established renal impairment were excluded. Fourteen normotensive controls were selected from the staff of the hospital.

Blood for isolation of the leucocytes was collected in heparinised syringes by venepuncture. Leucocytes were isolated by a modification of the method of Baron and Ahmed. ${ }^{8}$ The isolated cells were loaded with ${ }^{22} \mathrm{Na}$ by incubating them for 20 minutes in tissue-culture fluid (TC-199; Wellcome) containing ${ }^{22} \mathrm{Na} 0.9 \mathrm{mCi} / 1\left({ }^{22} \mathrm{NaCl}\right.$; Amersham). The rate constant for total sodium efflux was determined from the residual radioactivity in timed samples of leucocytes. That for ouabain-insensitive sodium efflux was determined in cells treated with ouabain before the beginning of the determination. The difference in rate constants between total and ouabain-insensitive sodium efflux gave the rate constant for ouabain-sensitive or active efflux.

Extracellular space was measured with an extracellular fluid space marker, ${ }^{125}$ I-polyvinylpyrrolidone (Amersham). Cell sodium and potassium were extracted overnight in $0.1 \mathrm{~N} \mathrm{HNO}_{3}$ and measured by internal standard flame photometry. Electrolytes in leucocytes were 


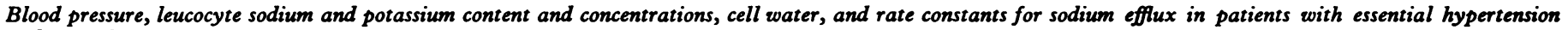
and controls

\begin{tabular}{|c|c|c|c|c|c|c|c|c|c|}
\hline \multirow[t]{2}{*}{ Subject } & \multicolumn{2}{|c|}{$\begin{array}{c}\text { Blood pressure } \\
(\mathrm{mm} \mathrm{Hg})\end{array}$} & \multirow{2}{*}{$\begin{array}{c}\text { Sodium } \\
\text { content } \\
\text { (mmol/kg } \\
\text { dry solids) }\end{array}$} & \multirow{2}{*}{$\begin{array}{l}\text { Sodium } \\
\text { concentration } \\
\text { (mmol/1 } \\
\text { cell water) }\end{array}$} & \multirow{2}{*}{$\begin{array}{l}\text { Potassium } \\
\text { content } \\
\text { (mmol/kg } \\
\text { dry solids) }\end{array}$} & \multirow{2}{*}{$\begin{array}{l}\text { Potassium } \\
\text { concentration } \\
\text { (mmol/1 } \\
\text { cell water) }\end{array}$} & \multirow{2}{*}{$\begin{array}{c}\text { Cell } \\
\text { water } \\
\text { (l/kg } \\
\text { wet weight) }\end{array}$} & \multirow[t]{2}{*}{$\mathrm{kOA}_{\mathbf{s}}$} & \multirow[t]{2}{*}{$\mathbf{k O A}_{\mathbf{I}}$} \\
\hline & Systolic & Diastolic & & & & & & & \\
\hline \multicolumn{10}{|c|}{ Hypertensives } \\
\hline $\begin{array}{r}1 \\
2 \\
3 \\
4 \\
5 \\
6 \\
7 \\
8 \\
9 \\
10 \\
11 \\
12 \\
13 \\
14 \\
15 \\
16 \\
17 \\
18 \\
19 \\
20\end{array}$ & $\begin{array}{l}170 \\
184 \\
166 \\
188 \\
148 \\
156 \\
166 \\
200 \\
160 \\
180 \\
110 \\
213 \\
160 \\
160 \\
158 \\
158 \\
148 \\
183 \\
160 \\
170\end{array}$ & $\begin{array}{r}108 \\
154 \\
120 \\
130 \\
112 \\
116 \\
116 \\
126 \\
108 \\
110 \\
92 \\
146 \\
112 \\
120 \\
130 \\
118 \\
124 \\
132 \\
90 \\
110\end{array}$ & $\begin{array}{r}45.5 \\
70.8 \\
90.3 \\
49.0 \\
144.2 \\
95.6 \\
120.6 \\
95.5 \\
93.4 \\
129.0 \\
125.0 \\
78.7 \\
81.1 \\
154.6 \\
125.8 \\
61.2 \\
109.5 \\
173.3 \\
70.0 \\
108.0\end{array}$ & $\begin{array}{l}20 \cdot 7 \\
50 \cdot 2 \\
45 \cdot 8 \\
22 \cdot 8 \\
89 \cdot 6 \\
38 \cdot 7 \\
57 \cdot 9 \\
75 \cdot 8 \\
44 \cdot 3 \\
58 \cdot 4 \\
36 \cdot 7 \\
35 \cdot 1 \\
37 \cdot 0 \\
62 \cdot 2 \\
43.6 \\
29 \cdot 4 \\
54 \cdot 2 \\
63 \cdot 5 \\
32 \cdot 0 \\
49 \cdot 3\end{array}$ & $\begin{array}{l}247 \\
224 \\
376 \\
326 \\
240 \\
301 \\
298 \\
344 \\
337 \\
351 \\
398 \\
344 \\
445 \\
353 \\
405 \\
392 \\
302 \\
238 \\
346 \\
383\end{array}$ & $\begin{array}{c}112 \\
159 \\
191 \\
152 \\
149 \\
122 \\
143 \\
273 \\
160 \\
159 \\
131 \\
153 \\
203 \\
142 \\
140 \\
189 \\
150 \\
87 \\
157 \\
175\end{array}$ & $\begin{array}{l}2 \cdot 20 \\
1.41 \\
1.97 \\
2 \cdot 15 \\
1.61 \\
2.47 \\
2.08 \\
1.26 \\
2 \cdot 11 \\
2 \cdot 21 \\
3.40 \\
2.24 \\
2 \cdot 18 \\
2.48 \\
2.89 \\
2.08 \\
2.02 \\
2 \cdot 73 \\
2 \cdot 19 \\
2 \cdot 20\end{array}$ & $\begin{array}{l}1.06 \\
1.51 \\
2 \cdot 26 \\
0.87 \\
0.95 \\
0.51 \\
1.71 \\
2.38 \\
1.80 \\
2.26 \\
3.00 \\
2.74 \\
1.45 \\
2.28 \\
3.20 \\
4.51 \\
1.16 \\
4.65 \\
2.73 \\
1.45\end{array}$ & $\begin{array}{l}0.44 \\
0.01 \\
0.66 \\
0.50 \\
1.35 \\
2.94 \\
0.56 \\
0.45 \\
0.16 \\
0.52 \\
0.61 \\
1.07 \\
1.06 \\
0.80 \\
0.03 \\
0.14 \\
2.84 \\
0.46 \\
0.71 \\
0.09\end{array}$ \\
\hline Mean $\pm S E M$ & $166.9 \pm 4.8^{*}$ & $118 \cdot 8 \pm 3 \cdot 6^{*}$ & $101 \cdot 1 \pm 7 \cdot 8 \dagger$ & $47 \cdot 4 \pm 3 \cdot 9$ & $332.0 \pm 13.6$ & $158 \cdot 0 \pm 8 \cdot 9$ & $2 \cdot 19 \pm 0 \cdot 11$ & $2 \cdot 12 \pm 0 \cdot 25$ & $0.77 \pm 0.18$ \\
\hline \multicolumn{10}{|c|}{ Controls } \\
\hline $\begin{array}{l}21 \\
22 \\
23 \\
24 \\
25 \\
26 \\
27 \\
28 \\
29 \\
30 \\
31 \\
32 \\
33 \\
34\end{array}$ & $\begin{array}{r}120 \\
124 \\
130 \\
126 \\
128 \\
136 \\
98 \\
138 \\
132 \\
130 \\
110 \\
124 \\
124 \\
130\end{array}$ & $\begin{array}{l}70 \\
72 \\
80 \\
80 \\
82 \\
80 \\
78 \\
84 \\
76 \\
68 \\
72 \\
86 \\
78 \\
84\end{array}$ & $\begin{array}{r}79.5 \\
108.0 \\
113.6 \\
89.8 \\
73.9 \\
125.8 \\
35.4 \\
89.7 \\
78.1 \\
56.7 \\
40.5 \\
59.0 \\
43.6 \\
49.7\end{array}$ & $\begin{array}{l}39 \cdot 8 \\
54 \cdot 2 \\
51 \cdot 6 \\
37 \cdot 1 \\
33 \cdot 0 \\
68 \cdot 7 \\
14 \cdot 1 \\
82 \cdot 1 \\
49 \cdot 4 \\
21 \cdot 1 \\
20 \cdot 4 \\
29 \cdot 4 \\
25 \cdot 5 \\
25 \cdot 1\end{array}$ & $\begin{array}{l}335 \\
333 \\
336 \\
366 \\
357 \\
277 \\
388 \\
373 \\
407 \\
317 \\
256 \\
357 \\
327 \\
358\end{array}$ & $\begin{array}{l}168 \\
167 \\
152 \\
151 \\
159 \\
151 \\
154 \\
189 \\
258 \\
132 \\
129 \\
177 \\
209 \\
181\end{array}$ & $\begin{array}{l}2.00 \\
1.99 \\
2.20 \\
2.42 \\
2.24 \\
1.83 \\
2.52 \\
1.07 \\
1.58 \\
2.40 \\
1.99 \\
2.01 \\
1.71 \\
1.98\end{array}$ & $\begin{array}{l}2.26 \\
1.19 \\
4.07 \\
3.27 \\
1.19 \\
3.49 \\
2.30 \\
3.63 \\
2.51 \\
2.76 \\
3.33 \\
3.50 \\
2 \cdot 81 \\
2.67\end{array}$ & $\begin{array}{l}0.63 \\
0.82 \\
0.58 \\
0.51 \\
0.01 \\
0.18 \\
0.12 \\
0.68 \\
0.68 \\
1.01 \\
0.84 \\
0.83 \\
0.64 \\
0.54\end{array}$ \\
\hline Mean \pm SEM & $125.0 \pm 1.5^{*}$ & $77 \cdot 9 \pm 1.5^{*}$ & $74 \cdot 5 \pm 7 \cdot 6 \dagger$ & $39 \cdot 4 \pm 5 \cdot 3$ & $341 \cdot 0 \pm 10 \cdot 8$ & $170 \cdot 0 \pm 8 \cdot 8$ & $2 \cdot 00 \pm 0 \cdot 10$ & $2 \cdot 78 \pm 0.23$ & $0.58 \pm 0.08$ \\
\hline
\end{tabular}

kOAs = Ouabain-sensitive rate constant for sodium efflux.

kOA $=$ Ouabain-insensitive rate constant for sodium efflux.

$\mathrm{p}<0.0001$

Conversion: $S I$ to traditional units-Sodium: $1 \mathrm{mmol}=1 \mathrm{mEq}$. Potassium: $1 \mathrm{mmol}=1 \mathrm{mEq}$.

expressed as content ( $\mathrm{mmol} / \mathrm{kg}$ dry solids) and concentration ( $\mathrm{mmol} / \mathrm{l}$ cell water).

Results are expressed as means \pm SEM. Significance of differences between values was measured by Student's $t$ test.

\section{Results}

The mean age of the controls was $38 \cdot 1$ years (range 22-55) and of the hypertensive patients 38.5 years (range 21-54). The mean blood pressures of the two groups were $125 / 78 \mathrm{~mm} \mathrm{Hg}$ and $167 / 119 \mathrm{~mm} \mathrm{Hg}$, respectively (table).

Leucocyte sodium content in the controls was $74.5 \pm 7.6 \mathrm{mmol}(\mathrm{mEq}) /$ $\mathrm{kg}$ dry solids and in the hypertensive patients $101 \cdot 1 \pm 7 \cdot 8 \mathrm{mmol} / \mathrm{kg}$ dry solids $(p<0.05)$. Sodium concentration was also higher in the patients than in the normotensive controls $(47.4 \pm 3.9 v 39.4 \pm 5.3$ $\mathrm{mmol} / \mathrm{l}$ cell water).

Leucocyte potassium contents were closely similar in the controls and hypertensive patients $(341.0 \pm 10.8 v 332.0 \pm 13.6 \mathrm{mmol}(\mathrm{mEq}) / \mathrm{kg}$ dry solids), as were leucocyte potassium concentrations $(\mathbf{1 7 0} \cdot \mathbf{0} \pm \mathbf{8 . 8} v$ $158.0 \pm 8.9 \mathrm{mmol} / 1$ cell water). Amounts of cell water were similar in the controls and hypertensives $(2 \cdot 00 \pm 0 \cdot 10 v 2 \cdot 19 \pm 0 \cdot 11 \mathrm{l} / \mathrm{kg}$ wet weight).

There was no significant difference in the rate constants for total sodium efflux, ouabain-insensitive, or ouabain-sensitive efflux between the two groups.

\section{Discussion}

In the only other reported study of this type, Edmondson et $a l^{7}$ found an increase in leucocyte sodium content and cell water, a reduction in leucocyte potassium concentration, similar contents of leucocyte potassium, but a reduction in total and active sodium efflux rate constants. They suggested that a defect in the sodium pump was the underlying cause of hypertension in English patients.

Increased concentrations of sodium in smooth muscle have been linked theoretically with increased peripheral resistance by several authors, ${ }^{910}$ and abnormalities in leucocyte sodium homoeostasis have been regarded as important by assuming that those leucocyte defects are shared by smooth-muscle cells.

Contrary to Edmondsonet al, we found no significant difference in the rate constants for sodium efflux, nor in cell water and leucocyte potassium concentration. The increased leucocyte sodium content in the presence of normal rate constants for sodium efflux (ouabain sensitive and insensitive) suggests that a defect in the sodium pump does not underlie the disturbance in cellular sodium homoeostasis. Since the two important variables which determine cell sodium are the rates of influx and efflux, the rate of sodium influx is apparently responsible for the increase in leucocyte sodium content, the influx rate having exceeded the efflux rate. Thus an abnormally enhanced membrane permeability to sodium ion must exist in leucocytes from our black hypertensive patients.

It is not surprising that the leucocyte potassium content was similar in the controls and hypertensive patients. Reportedly, after acute reduction of the rate constant for sodium efflux, the efflux rate $(k \times[\mathrm{Na}])$ falls as well but returns to normal when the intracellular sodium concentration increases enough to offset the fall in rate constant. ${ }^{11}$ During the period of acute reduction in efflux rate of sodium there is a similar reduction of influx rate of potassium, and, indeed, potassium content might fall if efflux exceeds influx. After sodium efflux returns to normal, however, potassium inclusion by the same pump also increases, thus returning cell potassium to normal. In leucocytes from our hypertensive patients the primary insult which resulted in the increase in sodium was not a reduction in rate constant but 
presumably an increase in membrane permeability to sodium. Regardless of the initiating factor, however, the next steps are identical-namely, increased sodium efflux and potassium influx leading to a return to normal of cell potassium.

The significance of the disturbances in cellular sodium homoeostasis is not clear, but if we assume that the changes in the sodium content of leucocytes are found in other cells then our findings may be relevant to the production or maintenance of hypertension. Increased sodium in smooth muscle has long been thought to cause the increase in peripheral resistance which is uniformly found in hypertension. Our findings indicate that there may be a different pattern of derangement of cellular sodium homoeostasis in black patients with hypertension.

\section{References}

${ }^{1}$ Eyer J. Hypertension as a disease of modern society. Int $\mathcal{f}$ Health Serv $1975 ; 5: 539-58$.

2 Dahl LK, Love RA. Relation of sodium chloride intake to essential hypertension in humans. Fed Proc 1954;13:426.

${ }^{3}$ Dahl LK, Love RA. Evidence for relationship between sodium (chloride) intake and human essential hypertension. Arch Intern Med 1954;94: 525-31.

4 Dahl LK, Heine M, Tassinari L. Effects of chronic excess salt ingestion: evidence that genetic factors play an important role in susceptibility to experimental hypertension. F Exp Med 1962;115:1173-90.

${ }^{5}$ Garay RP, Meyer P. A new test showing abnormal net $\mathrm{Na}^{+}$and $\mathrm{K}^{+}$fluxes in erythrocytes of essential hypertensive patients. Lancet 1979; i:349-53.

${ }^{6}$ Canessa M, Adragna N, Solomon HS, Connolly TM, Tosteson DC. Increased sodium-lithium countertransport in red cells of patients with essential hypertension. $N$ Engl f Med 1980;302:772-6.

7 Edmondson RPS, Hilton PJ, Thomas RD, Patrick J, Jones NF. Abnormal leucocyte composition and sodium transport in essential hypertension. Lancet $1975 ; \mathrm{i}: 1003-5$.

${ }^{8}$ Baron DN, Ahmed SA. Intracellular concentrations of water and of the principal electrolytes determined by analysis of isolated human leucocytes. Clin Sci $1969 ; 37: 205-19$.

9 Blaustein MP. Sodium ions, calcium ions, blood pressure regulation and hypertension: a reassessment and a hypothesis. Am $\mathcal{F}$ Physiol 1977 ;232: C165-73.

10 Tobian L. How sodium and the kidney relate to the hypertensive arteriole. Fed Proc 1974;33:138-42.

11 Patrick J, Hilton PJ. Characterization of sodium transport disorders in disease: different effects upon sodium and potassium of changes in the sodium pump and in membrane permeability. Clin Sci 1979;57:289-93.

(Accepted 30 March 1981)

\title{
Effect of naftidrofuryl on the metabolic response to surgery
}

\author{
H J G BURNS, D J GALLOWAY, I McA LEDINGHAM
}

\begin{abstract}
In a randomised study of 34 patients undergoing elective operations of moderate severity naftidrofuryl infusion significantly improved postoperative nitrogen balance. The control group excreted $26.2 \pm 2.7 \mathrm{~g}$ nitrogen in the first three postoperative days. A group treated with naftidrofuryl excreted $18.0 \pm 1.6 \mathrm{~g}$ nitrogen in the same period $(p<0.0005)$. The preoperative nutritional state of patients treated with naftidrofuryl did not differ from that of the controls.

Though hormonal changes causing an improvement in nitrogen balance could not be excluded by this study, the results show that naftidrofuryl infusion may stimulate postoperative catabolism of endogenous carbohydrate and fat, thus sparing tissue protein.
\end{abstract}

\section{Introduction}

Increased urinary excretion of nitrogen and reduced synthesis of tissue protein are accepted features of the metabolic response to injury. ${ }^{12}$ It is widely recognised that this alteration in protein metabolism leads to increased morbidity and mortality in injured patients, and hyperalimentation with protein and energy sources has been advocated as a means of improving prognosis after surgery. ${ }^{3}{ }^{4}$ Though intensive nutritional support may

\footnotetext{
University Department of Surgery, Western Infirmary, Glasgow G11 6NT

H J G BURNS, MB, FRCs, lecturer in surgery

D J GALLOWAY, MB, CHB, senior house officer (now surgical registrar, Royal Alexandra Infirmary, Paisley)

I MCA LEDINGHAM, MD, FRCSED, FRSE, professor
}

improve nitrogen balance postoperatively, the evidence that it will significantly alter outcome remains unconvincing. Several workers have suggested that inhibition of intracellular metabolic pathways may be the basis of abnormal protein metabolism after injury..$^{5-7}$ Pharmacological stimulation of cellular metabolism may therefore be a more specific means of improving nitrogen balance. Naftidrofuryl (Praxilene) may stimulate cellular metabolism after injury. We decided to investigate the possibility that this drug might modify postoperative nitrogen metabolism.

\section{Patients and methods}

Informed consent was obtained from 34 patients undergoing elective operations of moderate severity. Only patients who reported no preoperative weight loss were considered for study. They were weighed and their skinfold thicknesses measured in the four positions described by Durnin and Rahaman. ${ }^{8}$ These measurements were used to derive fat-free mass. They were then randomised into a control group or a treatment group according to the last digit of their hospital case number. On the morning of operation a 24-hour urine collection was started, and daily collections were continued for the study period, which was three days. Total urinary nitrogen was estimated by the method of Fleck. ${ }^{9}$ Plasma urea and electrolyte concentrations were measured daily.

Both groups received similar amounts of blood in the perioperative period and a standard fluid regimen consisting of isotonic dextrose and saline for three days postoperatively. Only water was permitted by mouth. During the study the treatment group received twice-daily infusions of $200 \mathrm{mg}$ naftidrofuryl given over one to two hours. The first infusion began with the induction of anaesthesia. A standard anaesthetic technique was used throughout.

\section{Results}

The 19 control patients undergoing operations of moderate severity excreted $26.2 \pm 2.7 \mathrm{~g}$ (mean \pm 2 SEM) of nitrogen in the three days 